\title{
Some Reflections on Age Discrimination, Referees' Retirement Ages and European Sports (Law)
}

\section{David McArdle}

\section{Introduction}

This paper is the first in a series of reflections on the relationship between discrimination, sport and the law, a body of work that has been motivated in part by the potential impact of the 2000 Equalities Directive upon European sports law, but also by developments in human rights jurisprudence and in the domestic laws of several jurisdictions. The phenomenon of age discrimination in sport, and the social and economic impact thereof, has been far less widely considered than is the case with other forms of sports discrimination (although the literature would miraculously emerge if the subjectmatter were more directly concerned with men's professional football). In contrast, free movement and competition law have impacted significantly upon sports provisions that discriminate on the basis of nationality; it is equally evident that age discrimination in the context of sports employment has not been considered with anything approaching the degree of sophistication that pervades our understanding of discrimination in occupation or employment on the grounds of disability, sexual orientation and religion/belief (the other discriminatory forms that are covered by the 2000 Directive); and our poor understanding of age-related sports discrimination generally stands in marked contrast to our appreciation of how challenges to discrimination on the grounds of sex and race have precipitated far-reaching changes to sports practices. Throughout the EU, with the possible exception of the Irish Republic, age discrimination law is far less advanced than is the case with discrimination which takes any of those other forms, the remedies are weaker and fewer people are aware of them. However, this state of affairs will undoubtedly change under the impact of the Equalities Directive, and even though the provisions themselves (and member states' transposing of them) attract legitimate criticism, some longstanding practices of sports bodies are now open to challenge.

Sports practices that may now come under scrutiny for their discriminatory impact on grounds of age include the widespread use of short fixed-term contracts for all participants over a given age; the 'homegrown player' rule as now practised in professional football; restrictions on the transfer of young footballers; and the retirement provisions applied to referees and other officials. Some will contend that these should fall outside the scope of EU law because they are examples of the 'specificity of sport', or are 'inherent' in the sports practice. This is just another way of saying 'we've always done things like this and we're not going to change without a fight', and sports bodies' resistance to change is well-documented, but the White Paper's affirmation that although 'there are organisational sporting rules that - based on their legitimate objectives - are likely not to breach the anti-trust provisions of the EC Treaty', the caveat that 'their anti-competitive effects, if any, (must be) inherent and proportionate to the objectives pursued ${ }^{1}$ reminds us that once one moves beyond such matters as the duration of a game, the placing of the limitations of the number of participants in a 
given competition and the provisions regarding national team composition, the 'specificity' arguments have little to commend them.

But this paper is concerned specifically with the early mandatory retirement ages for referees and other match officials - provisions that are a characteristic of most European sports federations' rules and thus seeks to locate those rules within the context of the Directive's provisions on age discrimination generally. More broadly, it also considers the EU policy developments that form the background to the age discrimination provisions, and the jurisprudence of the ECJ and the domestic courts to the extent that it is of relevance. Mandatory early retirement ages for match officials represent one example of a policy that goes far beyond what is necessary because of the 'specificity' of sport, and they go far beyond the degree of latitude that the Directive gives employers with regard to retirement ages generally. Indeed, such sporting provisions have already been condemned under the domestic laws of at least two member states: in the Dutch case of Uilenberg $v K N F B{ }^{2}$ which predates the Directive, a number of football referees sued the domestic governing body over a rule which provided that no-one over the age of 47 could be a referee in the Dutch professional league and noone older than 49 may be an assistant referee in the Dutch professional league. The court ruled that there were more objective ways (such as eye tests and fitness tests) to determine whether someone was still capable of dealing with high level matches and therefore the age discrimination was disproportionate and unlawful. Although it remains the case that not all age-based discriminatory practices in the employment context are unlawful, if one considers the broader economic and social policy issues underpinning the Directive, and the caselaw emanating from it, it becomes ever more clear that the retirement provisions utilised in sports cannot be regarded as serving any legitimate sporting objectives; they cannot be reconciled with the Directive's provisions; and they were unlawful in some member states even before the Directive came into being.

\section{The European law framework}

In order to illustrate the difficulties with mandatory retirement provisions, it is important to ascertain what EU age discrimination law is 'about', if only to facilitate rebuttal of some of the potential arguments that might be advanced in favour of the existing retirement regimes. Directive 2000/78 the Framework directive - came into force in December 2000 and established a general framework for equal treatment in employment and occupation by prohibiting discrimination on grounds of religion/belief, disability, age or sexual orientation. The Directive is a consequence of the developments in EU policy that have occurred since 1997, notably the EU Treaty commitment to protect fundamental human rights, which was strengthened by the Treaty of Amsterdam, Art 6; the prohibition of certain grounds of discrimination in the EC Treaty; and both the EC and EU Treaties' commitments to the promotion of a high level of employment (this being manifested by the 
introduction of a new EC Treaty Title on Employment and the launch at the Luxembourg Summit in November 1997 of the European Employment Strategy).

Article 6(2) of the Amsterdam Treaty provides that:

The Union shall respect fundamental rights, as guaranteed by the European Convention for the Protection of Human Rights and Fundamental Freedoms...and as they result from the constitutional traditions common to the member states, as general principles of Community law.

New Article 13 of the EC Treaty (complementing the existing Article 12 prohibition on discrimination on the grounds of nationality) provides that the Council, 'acting unanimously on a proposal from the Commission and after consulting the European Parliament, may take appropriate action to combat discrimination based on sex, racial or ethnic origin, religion or belief, disability, age or sexual orientation.' Further, Article 2 of the EU Treaty now commits the Union to promoting 'economic and social progress and a high level of employment', while the revised Article 2 of the EC Treaty provides for (inter alia) the implementation of 'common policies or activities...to promote throughout the Community a harmonious, balanced and sustainable development of ... a high level of employment.' New Title VIII of the EC Treaty gives the Commission and the Council a greater role in helping achieve these aspirations by working with the member states in order to develop 'a coordinated strategy for employment and particularly for promoting a skilled, trained and adaptable workforce and labour markets responsive to economic change with a view to achieving the objectives defined in Article 2.'

The emergence of these new provisions coincided with a rising awareness of the twin, related problems of long-term unemployment and an ageing workforce across the European Union. The Lisbon Special European Council of March 2000 had recognised that Europe's population was ageing and would continue to do so, but also that the proportion of older people in employment was far too low. For example, in the United Kingdom the number of people aged over fifty is predicted to rise from 19.8 million in 2005 to 24.5 million in 2020, while those aged between 16 and 24 is predicted to fall from 6.9 million to 6.6 million over the same period. One consequence of this is that between 2006 and 2020, the number of people aged over 64 as a proportion of the number of people aged 1864 (the 'old-age dependency ratio') will rise from $23.8 \%$ to $29.7 \% .^{3}$ Mindful of this inexorable move towards an older population, the European Commission's 2000 Review $^{4}$ announced that 'major policy efforts will be necessary' to increase the number of women and men aged 55 and over who are in employment, while the December 1999 European Council meeting in Helsinki had recognised the need to 'develop a policy for active ageing encompassing appropriate measures such as maintaining working capacity, lifelong learning and other flexible working arrangements so that older workers are also able to ... participate actively in working life. ${ }^{5}$ In March 2001, the Stockholm summit set a 
target for $50 \%$ of those aged between 55 and 64 to remain in the workforce by 2010, an increase of $12 \%$ on the figure at that time. This goal remains an important part of what is now known as the Lisbon Strategy.

Directive 2000/78 EC establishes a 'general framework for equal treatment in employment and occupation', covering religion/belief, disability, age and sexual orientation with a view to putting into effect in the member States the principle of equal treatment. ${ }^{6}$ The Directive's recitals refer to the commitments to equal treatment and achieving full employment, and states that the right to 'equality before the law and protection against discrimination' is a universal right, referring in particular to the Community Charter of the Fundamental Rights of Workers (which 'recognises the importance of ... the need to take appropriate action for the social and economic integration of elderly and disabled people') and the 2000 Guidelines' emphasis on 'supporting' older workers and 'increas(ing) their participation in the labour force.

Importantly, Recital 21 of the Directive provides that differences in treatment can be justified if there is a 'genuine and determining occupational requirement, when the objective is legitimate and the requirement is proportionate'. With regard to age discrimination specifically, Recital 25 provides that

Differences in treatment in connection with age may be justified under certain circumstances and therefore require specific provisions which may vary in accordance with the situation in Member States. It is therefore essential to distinguish between difference in treatment which are justified, in particular by legitimate employment policy, labour market and vocational training objectives, and discrimination which must be prohibited.

Recital 14 clarifies that the Directive shall be "without prejudice to national provisions laying down retirement ages', while Recitals 18 and 19 make provision for derogations in respect of the armed forces; along with the police, prison and emergency services, the armed forces are not required to recruit or retain those persons who do not have the 'required capacity to carry out the range of functions that they may be called upon to perform'.

Article 2(1) provides that there 'shall be no direct or indirect discrimination whatsoever' on the proscribed grounds, with those concepts being defined in Article 2(2)(a) and (b) respectively, while Article 3(1) provides that the Directive applies to both the public and private sectors and pertains to conditions of access to employment and self-employment, including selection criteria and recruitment; access to vocational guidance, training and work experience; employment and working conditions including dismissals and pay; membership of workers' and employers' organisations. Article 4(1) allows for differences in treatment where a characteristic related to any of the four grounds 'constitutes a genuine and determining occupational requirement, provided that the objective is legitimate and the requirement is proportionate. Article 4(2) provides further details in respect of the 
'religion and belief' ground, but there is no further consideration of it in relation to age discrimination. ${ }^{?}$

With regards to the central question (for the purposes of this paper) of the legality of retirement ages, Article 6(1) of the Directive provides that:

Differences of treatment on grounds of age shall not constitute discrimination if, within the context of national law, they are objectively and reasonably justified by a legitimate aim, including legitimate employment policy, labour market and vocational training objectives, and if the means of achieving that aim are appropriate and necessary.

Article 6(1)(a) goes on to provide that 'such difference may include, among others' allowing conditions governing access by young people, older workers and persons with caring responsibilities.

\section{The UK provisions}

Within the United Kingdom, transposition of the age-related aspects of the Framework Directive has been achieved through the Age Regulations $2006,{ }^{8}$ which came into force on October $1^{\text {st }}$ of that year. Initially, the discussions on transposing the age discrimination aspects of the Directive occurred in a number of consultation papers, namely 'Towards Equality and Diversity' ${ }^{9}$ published in 2001, 'Equality and Diversity: Age Matters ${ }^{10}$ published in 2003 and, finally, 'Equality and Diversity: Coming of Age, ${ }^{11}$ which was published in 2005. In the first two documents the government outlined the need to strike the balance between complying with its obligations under the Directive and avoiding unnecessary burdens on business, and of the need to end 'the substantial cost of discriminatory age practices to individuals (and) the wealth of the nation, ${ }^{, 12}$ but it was also clear that the government did not regard the Framework Directive as heralding an end to mandatory retirement:

It will not constitute age discrimination if employers retire employees at or above the age of 65 . Lower retirement ages will only be possible if the employer can objectively justify them. The Age Regulations will set out a new procedure that will have to be used for any compulsory retirement - the 'duty to consider' procedure. ${ }^{13}$

The 2005 document similarly asserted that the Framework Directive 'allows age discrimination if it can be objectively justified...the government is convinced that the proposed national retirement age can be so justified'. ${ }^{14}$ The Directive itself is largely silent on the subject of mandatory retirement ages, save for Paragraph 14 of the Preamble which says its provisions shall be 'without prejudice to national provisions laying down retirement ages', and the provisions of Article 6 .

The Framework Directive was thus regarded as an opportunity for mandatory retirement provisions to be more firmly entrenched, in accordance with the wishes expressed by employers throughout the 
consultation process. ${ }^{15}$ Historically, the problem for UK employees who wished to challenge their standard retirement age was the provision (contained most recently in the Employment Rights Act 1996, s. 109) that employees could not claim unfair dismissal if they had reached either the 'normal retirement age for an employee holding the position which he held', or if there was no normal retirement age within that undertaking, the statutory retirement age of 65 years. In accordance employers' wishes, it was proposed in the 2005 Consultation Document that there would be a 'default retirement age' of 65 (as opposed to a default retirement age of 70 that had been proposed in the 2003 document) unless the employer had a lower normal retirement age, together with a proviso that the upper age limits on unfair dismissal and redundancy pay would cease to exist. Sargeant predicted that 'it will be difficult to argue that the allowing of compulsory retirement does not amount to less favourable treatment so (the government) must therefore be able to objectively justify the introduction of this new concept of a national default retirement age. Employers and employees can agree about retirement and then the default retirement age need not apply, although compulsory retirement before the age of 65 is to become unlawful, without further justification. ${ }^{16}$ For Sargeant, the Regulations as enacted thus reflected employers' assumptions that older workers would decline in competence and that a mandatory retirement age was preferable to situations in which employees wanted to continue working but employers wanted them to retire because their age was impacting upon their ability to do the job. In contrast, the union movement wanted to encourage the use of collective agreements and asserted that 'failing competency is a completely different issue from ageing and the two should be clearly separated'. ${ }^{17}$

\section{Retirement ages: the caselaw}

The first referral to the ECJ on the retirement provisions was Mangold $v$ Helm. ${ }^{18}$ The case arose as a consequence of a German law that sought to address the particular problem of a lack of opportunities for older workers, with fixed-term employment thus being regarded as a preferable alternative to unemployment. The legislation in question ${ }^{19}$ allowed for the use of fixed-term employment contracts if there were objective grounds for using them (those grounds being outlined in s. 14(1) the legislation), but following amendment in 2002 there was no need for the objective justification of fixed-term contracts if the employee had reached the age of 52 at the time of the contract's commencement. Mangold, aged 56, challenged the legality of a fixed-term contract of eight months' duration on the ground that it contravened both Directive 1999/70/EC on fixed-term work (which was implemented by the domestic provision in question) and the Framework Directive. In its referral under Article 234 the German labour court asked whether the Directive rendered the German legislation unlawful because it differentiated on the grounds of age and, if so, what conclusions should be drawn from that interpretation. ${ }^{20}$ 
It was clear that different treatment on the basis of age would be unlawful under Article 2(1) of the Directive unless justified under Articles 4 and 6. However, it would not have been unreasonable for the Court to answer that because the Directive did not have to be implemented at the time that Mangold entered into the employment relationship, German employment law did not have to comply with it at that time; and that even if implementation had been required by that time, Mangold could not have relied on the Directive because, in accordance with Marshall v Southampton and South-West $A H A,{ }^{21}$ a Directive may not, of itself, impose obligations on an individual.

Instead, the ECJ took a far less predictable tack, resulting in what Krebber calls 'the most surprising and puzzling, but at the same time most interesting decision dealing with employment law for thirty years. ${ }^{22}$ First, the Court did not follow the Advocate General's ruling, in which he favoured the approach taken in the Spanish case of Caballero v Fondo de Garantia Salarial to the effect that the legislation contravened the general principle of equal treatment in respect of Directive 80/897. Instead, it 'characterised the prohibition to discriminate on grounds of age (in the Framework Directive) as a fundamental right under Community law, thus making it more difficult for Member States to justify different treatment of persons as opposed to different treatment of factual circumstances. At the same time, the Court seemed to consider the prohibition to discriminate on grounds of age as autonomous from the Directive. ${ }^{23}$ This was achieved through reference to 'the source of the actual principle underlying the prohibition (of age discrimination)' being found in 'various international instruments and in the constitutional traditions common to the Member States' ${ }^{24}$ but precisely what 'international instruments' were relevant was never revealed. The Framework Directive does not lay down a principle of equal treatment in the field of employment and Krebber clearly shows ${ }^{25}$ that neither is such an underlying principle to be found in these 'instruments' or in 'constitutional traditions.' To the contrary, the ECJ's approach in Mangold was simply an example of what Bourdieu calls 'the law's power to do things with words'.

That done, the ECJ then considered whether the difference in treatment on grounds of age could be 'objectively and reasonably justified by a legitimate aim' as envisaged under Article 6 of the Directive:

The purpose of the legislation at issue was to promote the vocational integration of unemployed older workers, in so far as they encountered considerable difficulties in finding work. That was a legitimate public interest objective, which justified 'objectively and reasonably' a difference in treatment on grounds of age. ${ }^{26}$

However, 'it is not only the objective that needs to be legitimate, but the means used to achieve the objective need to be 'appropriate and necessary". ${ }^{27}$ Thus the Court went on to ask whether the measure was a proportionate means of achieving that objective and answered in the negative: the 
measure 'went beyond what was appropriate and necessary in order to attain the objective pursued" ${ }^{28}$ and it concluded by saying that

It was the responsibility of the national court to guarantee the full effectiveness of the general principle of non-discrimination in respect of age, setting aside any provision of national law which might conflict with Community law, even where the period prescribed for transposition of that Directive had not yet expired. ${ }^{29}$

Mangold has been the subject of considerable discussion, ${ }^{30}$ but its potential has been tempered by the subsequent ECJ decision in Palacious de la Villa v Cortefiel Servicios. ${ }^{31}$ Here, a manager with 24 years' service was notified of the automatic termination of his employment contract on the ground that he had reached the compulsory retirement age of 65 . That compulsory age had been set down in a collective agreement, the rationale for which was that mandatory retirement was 'in the interests of promoting employment'. The applicant contended that he had been dismissed while the Spanish government said he had been obliged to retire in accordance with national rules. It defended the measure on two grounds: first, by Recital 14, the Directive did not apply at all to retirement ages; and second that it was objectively justified under Article 6 in any event.

Three separate laws were of relevance to the case: an original law dating from 1980 (but repealed in 2001) which provided for a blanket exemption for compulsory retirement ages reached by collective agreements; a later provision (Law 14/2005) which reinstated the 1980 law to reflect changes in the government's employment policy; and an interim measure which was attached to that Law. The 2005 Law carried with it two conditions: first, nobody could be retired until they had made sufficient contributions to qualify for a pension and, second, the agreement had to be in pursuit of an economic policy. The interim measure applied to retirement agreements negotiated between 2001 and 2005 but it provided that only the first of those two conditions would apply. Put another way, any retirement provisions negotiated collectively between 2001 and 2005 did not have to be linked to an explicit economic policy. The Spanish court referred two questions: first, does the prohibition of age discrimination in Article 2(1) preclude a national law allowing the inclusion of compulsory retirement ages in collective agreements; second, if the answer to that is 'yes' would the relevant national law have to be repealed?

In his Opinion, Advocate General Mazak said Recital 14 provides that the Directive is to be without prejudice to national provisions that lay down retirement ages. He went on to say that 'I find it somewhat difficult not to regard the national rule as a provision of the kind envisaged by the recital, ${ }^{32}$ and that

Even though Article 6 of the Directive provides for specific exceptions and limitations with regard to age discrimination, it would, in my opinion, still be very problematic to have this 
Sword of Damocles hanging over all national provisions laying down retirement ages, especially as retirement ages are closely linked with areas like social and employment policies where the primary powers remain with the member states. ${ }^{33}$

He concluded that the provision in question 'cannot therefore be precluded by the prohibition of discrimination on the grounds of age ${ }^{34}$ and it could be justified under Article 6(1): it had been adopted at the instigation of the social partners as part of a policy promoting inter-generational employment. In the Advocate General's view, the policy thus 'serves a legitimate public-interest aim of employment and labour market policy capable of justifying a difference of treatment...in accordance with Article 6(1). ${ }^{35}$

While the Advocate General reiterated the Mangold court's point that Member States 'enjoy broad discretion in their choice of the measure capable of attaining their objectives in the field of employment and social policy, ${ }^{36}$ he took a contrary view on whether provisions for compulsory retirement went beyond what was 'appropriate and necessary for the attainment of the objectives pursued. ${ }^{37}$ Even if the Directive were interpreted as covering national provisions, he said, it would not preclude them. As to the Mangold finding that the principle of non-discrimination on the grounds of age was a general principle of EC law, he took the view that

It is actually a bold proposition and a significant move to infer, solely from the general principle of equal treatment, the existence of a specific prohibition of discrimination on grounds of age. ${ }^{38}$

The Mangold approach, he said, was 'far from compelling' and if its reasoning were followed to its logical conclusion then "not only prohibition on grounds of age, but all specific prohibitions of the types of discrimination referred to in Article 1 would have to be regarded as general principles of Community law. ${ }^{39}$ The principle of non-discrimination does not go so far as to preclude national rules which are designed to service Member States' legitimate economic, employment and social policies.

In its consideration of the case, the ECJ said that Recital 14 'merely states that the Directive does not affect the competence of the Member States to determine retirement age and does not in any way preclude the application of that Directive to national measures governing the conditions for termination of employment contracts where the retirement age, thus established, has been reached. ${ }^{40}$ Spain's compulsory retirement age was 'for the purposes of checking unemployment', and because the promotion of a high level of employment was an important Community objective, it was a legitimate aim (within the meaning of Article 6) for a Member State to aspire to. The Court also held that the measure was an appropriate and necessary one for achieving that aim, given that the imposition of a retirement age can promote full employment by facilitating access to the labour 
market; that the law also made provision for an appropriate retirement pension; and the law also allows for retirement ages to be fixed by collective agreement (thereby allowing both the general labour market and the specific features of the job to be taken into account). Taken in isolation, the transitional measure was not sufficiently precise to attain a 'legitimate goal', but when looked at in its broader context it did fulfil a legitimate aim: the original measure sought to create vacancies at a time of high unemployment, the transitional measure was adopted at the instigation of the trade union movement and employers' organisations to promote intergenerational employment, and the 2005 Law was similarly enacted with the co-operation of those two organisations (this time with various policy aims in mind). Finally, the compulsory retirement clause was deemed to be 'in the interests of promoting employment.'

Palacios is thus authority for the proposition that a particular measure 'need not express its social or employment policy purpose, so long as there is evidence that the policy exists, ${ }^{41}$ but it does not overcome the fundamental difficulty that attends sports organisations - namely, the problem of establishing that their retirement policies can be regarded as a proportionate response to a 'legitimate goal' even though the courts will need to be mindful of an undertaking's margin of appreciation on the issue. In this case the ECJ has resiled from the Mangold approach, where a policy which sought to help unemployed older workers could not be objectively justified because it was not tailored to those unemployed older workers (so it could not be deemed 'necessary'), but the Spanish government's policy of retiring older workers does not really assist in the 'promotion of full employment' - it just massages the unemployment figures because those laid off are characterised as 'retired' rather than 'unemployed', so in actual fact the policy discriminates against those whom the Directive was most designed to protect. ${ }^{42}$

So far as the UK's retirement provisions are concerned, Palacious is, at the time of writing, relevant to two ongoing cases. First, in the case of $R v$ Secretary of State for Business, Enterprise and Regulatory Reform ${ }^{43}$ the Queen's Bench Division has referred several questions to the ECJ under the Article 234 procedure on the broad issue of whether the 2006 Regulations' provisions on retirement age were compatible with the Directive. On the basis of the ECJ's decision in Palacious (which was handed down in October 2007, three months after the referral occurred) one would anticipate that the ECJ will respond to the effect that the Regulations' provisions are indeed compatible. However, it should be noted that the two cases concern rather different issues - Palacious concerned collective agreements on retirement ages whereas Heyday is concerned with whether Regs 7 and 30 of the UK Regulations amount to a national provision on retirement ages - so there is a little scope for the ECJ to reach a different decision in the latter case. That being the case, in Johns $v$ Solent SD Ltd ${ }^{44}$ the EAT allowed an appeal against a tribunal chair's decision to strike out a claim raising similar issues to Heyday, that decision being taken on the basis of the Advocate General's opinion in Palacios rather than the decision of the Court, which was not handed down until three months after the tribunal's 
decision to strike out. The EAT was clear that 'the tribunal chairman should not have been tempted down the path of pre-judging the decision in Heyday ${ }^{45}$ and ordered the proceedings be stayed pending the ECJ's decision in Heyday rather than struck out altogether.

\section{Retirement ages and the legitimate interests of sports bodies}

Given what is known about the age provisions of the Directive, the relevant ECJ caselaw and the United Kingdom's provisions, perhaps it is now possible to consider the legality of the referees' retirement age provisions with a degree of clarity.

For better or worse, Palacios establishes that mandatory retirement ages may be a proportionate means of attaining the legitimate social aim of promoting employment opportunities and reducing unemployment. An employer can have a normal retirement age of above 65 and if none is set the statutory retirement age applies, but compulsory retirement below 65 will be unlawful unless it can be objectively justified as a proportionate means of achieving a legitimate aim. Put another way, and to take the United Kingdom as an example, there is not a 'retirement' situation 'if the normal retirement age is not respected, if there is no normal retirement age and the employee is dismissed before 65 , or if there is an unjustified normal retirement age of under $65,{ }^{46}$ Thus the challenge for sports bodies is to determine whether they should seek to maintain a normal retirement age of under 65 , and if so how such a scheme could be regarded as justifiable - no easy task given the widespread use of mandatory fitness tests, but not impossible given the physical and mental demands on top-flight match officials. Recitals 18 and 19 provide that some employers are able set a lower mandatory retirement age - the police and armed forces are obvious examples - and the UK Regulations make similar provision, but those exceptions aside, lower mandatory retirement ages will only be sustainable if there is a manifest justification for their existence.

If there is a normal retirement age of 65-plus, then in the UK the employer the dismissal will be a fair one so long as it takes place on the normal retirement date and the statutory procedure (under Schedule 6 of the Regulations) obliging the employer to inform and to consider any request from the employee that they do not retire at that time has been followed. The employer can also dismiss if there is a normal retirement age of below 65 and the consultation procedure has been respected, or if there is no normal retirement age and dismissal occurs at 65 or over - and, again, if the duty to inform having been respected. ${ }^{47}$ If the duty to inform and consider results in an employee being kept on, then ordinarily a new retirement date will be set (thus effectively allowing the employee to continue in their employment for a fixed term). ${ }^{48}$

But how does one establish whether particular steps taken are 'proportionate'? Jonathan Swift advances the following proposition: ${ }^{49}$ 
(T)he proportionate means criterion under the Age Discrimination Regulations should require an employer to convince a tribunal of the following. First, that treatment that has been afforded to the claimant is rationally related to the aim he (the employer) has identified. Secondly, that he has not based the specific action taken against the claimant on uninformed assumptions about the claimant which are based on the age of the claimant. Thirdly, that he has taken reasonable steps to inform himself on all the material considerations prior to taking action against the claimant. Fourthly that the action taken represents a reasonable balance between the employer's pursuit of the aim actually pursued and the cost to the individual of that aim being pursued - i.e. that the action taken against the claimant is not an obviously excessive step having regard to the benefits that might reasonably be expected to accrue to the employer.

There is, of course, no a priori link between age and physical capabilities; the research of Bangsbo et al on the fitness levels of elite football referees in Denmark indicated that "physical activity and match performance were not lowered with age', ${ }^{50}$ and while they stressed that regular and proper training was particularly important for referees aged forty and over, there is nothing in the literature to suggest that referees in these, or any other sports, become less capable of fulfilling their role once they pass a particular date in the calendar: they key should be their performance in the fitness and other tests, not their biological age. That said, it is entirely right and proper for sports bodies to demand that officials are (to quote the website of European football's governing body) 'fully prepared technically and mentally to officiate and to require referees to take objective, measurable and relevant fitness tests that are appropriate for the level at which they are involved. ${ }^{, 51}$ With that in mind, it is well-established that the performance of referees is related to their fitness levels and that intense intermittent training can markedly improve their performance regardless of their age,$^{52}$ so if objective tests of the type that are utilised in most sports can monitor referees' physical prowess it would seem that the mandatory retirement rules pertaining to referees in football, and in many other sports, go much further than is necessary to secure a legitimate goal.

Football's provisions, for example, provide that referees for international games must be at least 25 years of age (although the reality is that they only achieve international status at the age of 35-40 years, ${ }^{53}$ ) and they can no longer perform at that level once they pass the age of 45 . Furthermore, there is another age-based restriction in that once a candidate has reached the age of $38 \mathrm{~s} / \mathrm{he}$ cannot apply for promotion to a category in which they have not previously officiated anyway. At the domestic level in the United Kingdom, it falls to national governing bodies make provision for the registration and control of referees, so for example the English Football Association sets a compulsory retirement age of $48,{ }^{54}$ while in Italy the figure is 45 although there are moves for that to be raised to 48 as well. ${ }^{55}$ Ergo, in addition to the fundamental problem of retirement ages it is apparent that both the 
international governing body's provisions dealing with international games and the domestic authorities' provisions dealing with club matches also use age as criterion for employment and promotion - a provision which is both contrary to the Directive and possesses a cross-border element because they restrict referees' opportunities to officiating at international competitions, and which flies in the face of the logic underpinning the use of objective, measurable fitness tests.

Similarly FIBA Europe, the governing body of basketball in Europe, requires all referees to pass the theoretical and physical fitness examinations organised by its technical commission and to take refresher courses. Referees appointed to the elite international panel - and thus be eligible for single match fees of 400 Euros - must be aged between 25 and 35 on the occasion of their appointment, and the Regulations provide that their licence 'may be renewed until the referee reaches the maximum age set by the Board of FIBA in Europe. ${ }^{56}$ However, an important difference is that while its documentation states that all referees' licences 'shall remain valid until the referee reaches the maximum age set by (FIBA Europe), ${ }^{57}$ nowhere is a mandatory retirement age actually set down. According to a FIBA official, 'there used to be a firm rule that referees retire at aged fifty - or at least they don't get nominated for the international games after fifty - and while that will remain until somebody challenges it, this has been relegated to an 'unspoken rule' for the time being. ${ }^{58}$ Equally, the international governing body of ice hockey stresses that 'fatigue can have a direct negative effect ... it can slow down your reaction time and cloud your judgement' and says that referees are expected to 'skate as fast in the third period as in the first' and to be able to 'keep up with play" even when there have been long periods without stoppages. ${ }^{, 59}$ There are mandatory fitness and skating test that vary according to the level at which one is officiating (with five levels ranging from youth to elite international) and the mandatory maximum age for referees and linesmen is at the more generous at fifty years. ${ }^{60}$

But could a retirement age of forty-five for football, or fifty for basketball, ever represent a 'proportionate means of achieving a legitimate aim' and therefore be in compliance with the Directive? There may be scope for different sports having different retirement ages, but that would depend in large part on whether it can be shown that different sports practices make different demands on match officials. And yet the fundamental difficulty remains; namely, the problem in establishing that any automatic retirement age for referees is defensible given that age-based criteria are necessarily arbitrary and make no provision for the different competencies of individuals, which do not disappear simply because they reach a particular point on the calendar, and given that sports bodies' retirement provisions can hardly be said to be linked to a wider, legitimate, economic and social policy as was at issue in Mangold and Palacious. While of course it is true that older people tend to be less fit, or are less likely to enjoy 20/20 vision, than younger people, it is also the case that 'people who exercise significant social power ought to do so rationally. They ought to make decisions by reference to relevant considerations, and ignore irrelevant considerations. ${ }^{61}$ An individual 
referee's chronological age is an irrelevant consideration; a relevant consideration - indeed, the only consideration that should matter - is whether their performance in rigorous, objective, scientificallyunderpinned fitness tests confirms that they are still able to meet the specific demands that their particular role demands of them. The variations in retirement ages between sports illustrate that agebased restrictions are merely arbitrary, usually being little more than an administrative convenience or, as may be the case with age discrimination in sport more generally, perhaps there is a bigger issue in that older officials (regardless of their competence and fitness levels) just do not fit the image that sports are trying to present to the media and the wider public.

For sports bodies, the use of physical fitness and other tests provide a far more proportionate means of advancing legitimate aims - namely, ensuring the referees are mentally and physically able to do the job. The use of early, arbitrary retirement ages comfortably exceed what is necessary to serve any legitimate justifications that sports organisations may have for them. While sports organisations may adopt the argument that they would rather have mandatory retirement ages than be confronted with the situation in which referees lacking the necessary physical competence desperately seek to hold on to what they love for too long, a contrary view is that the existence of mandatory retirement ages, together with the age-based pre-requisites that restrict promotion opportunities, simply reflects a more or less explicit desire to make opportunities for younger elite-level referees - a policy which may be just another example of sports-bodies' well-documented resistance to change (it's just 'the way things are', or 'we've always done it this way'); or it might be linked (implicitly) to a more worrying concern with how a particular sport 'looks' to audiences, broadcasters and potential sponsors.

\section{A possible way forward?}

Much has been written, in this tome and elsewhere, about the future of European sport in the aftermath of the Commission White Paper, and about the potential role of the social dialogue in resolving sporting disputes. Indeed, paragraph 5.3 of the White Paper explicitly commends the social dialogue as a means of

addressing common concerns of employers and athletes, including agreements on employment relations and working conditions in the sector in accordance with EC Treaty provisions.... European social dialogue in the sports sector...is an instrument which would allow social partners to contribute to the shaping of employment relations and working conditions....(It ) could also lead to the establishment of commonly agreed codes of conduct or charters, which could address issues related to training, working conditions or the protection of young people.

But is there really the scope for a social dialogue to consider any of the issues raised in the White Paper, let alone the matters pertaining to age discrimination (which the White Paper does not address 
at all)? The sporting field's resistance to change is not restricted to those who may be regarded as 'employers' but is rather a characteristic shared by all those in positions of dominance, which means that the Directive's age provisions require sports organisations to introduce changes that none of the stakeholders are agitating for, and while the White Paper commends football as a specific sub-sector where social dialogue might have a role more broadly, the oft-made point that there is no clear employers' organisation within that sport that the other social partner could negotiate with $^{62}$ applies equally to many other sports practices. While the partners in some sports may appear better-placed than others to avail themselves of the social dialogue opportunities - professional cycling would seem to represent one example ${ }^{63}$ - in most sports, referees' specific interests are represented through their membership of employers' panels and committees rather than through an independent entity. ${ }^{64}$

If the social dialogue could be utilised successfully, it would be open to the social partners to "make recommendations to their members and for the social partners to undertake to follow them up at national level” ${ }^{\prime 65}$ by way of codes of conduct, best practice guidelines and framework agreements because the 2001 Laeken Declaration ${ }^{66}$. committed the social partners to "more emphasis on autonomous, bi-partite dialogue aimed at the conclusion of voluntary, non-legally binding agreements", to be implemented through negotiations between unions and employers rather than their agreements evolving into Directives. So the social dialogue, whatever its faults, certainly has the potential to afford direct access to the policy process on a wide range of sporting issues - if only the structural issues of who negotiates with whom, and on whose behalf they have the authority to conclude agreements, can be overcome. ${ }^{67}$

With that in mind, perhaps there is scope for sports to engage in a cross-sector dialogue, or for individual sports to commence their own processes, on the whole range of age discrimination issues that are, at best, touched upon only briefly in this paper. As a starting-point, the governing bodies and other interested parties representing sports at the European level could explore whether their retirement ages could be set at an age where scientific data confirms it is statistically unlikely that referees would be able to meet the standards laid down in the objective physical tests applicable to each sport, together with the possibility of a two-year extension to accommodate any exceptional cases (Europe's population may be getting older, but it is also getting a lot healthier ${ }^{68}$ ); there may be legitimate reasons for having different mandatory retirement ages in different sports, but in any given sport the retirement ages for officiating in domestic competitions would have to be equalised across all the member states; and any reference to age criteria in an official's promotion from one tier to another would have to be removed in all sports at all levels. This would address the perfectly legitimate requirement that a match official's continuation or promotion should always be based on him/her meeting the objective requirements of the mandatory fitness test ${ }^{69}$ and their failure to reach that standard would result in their being ineligible for selection at that level after the end of the current season, together with officials being offered clear opportunities to use their skills and 
experience at a lower level of competition. The test should be repeated at least bi-annually at all levels on the pyramid, and ideally, annually at the elite levels, to ensure standards are maintained.

This does not afford a perfect solution by any means, but resolving the conundrum of officials' retirement in a manner that serves the social and economic rationales underpinning age discrimination laws while protecting the legitimate, objectively justifiable, interests of sports would go some way to facilitating European sports' compliance with both the law and good management practice. And it might also pave the way for a workable, mutually beneficial, basis on which the wider relationship between age, discrimination and sports could be discussed.

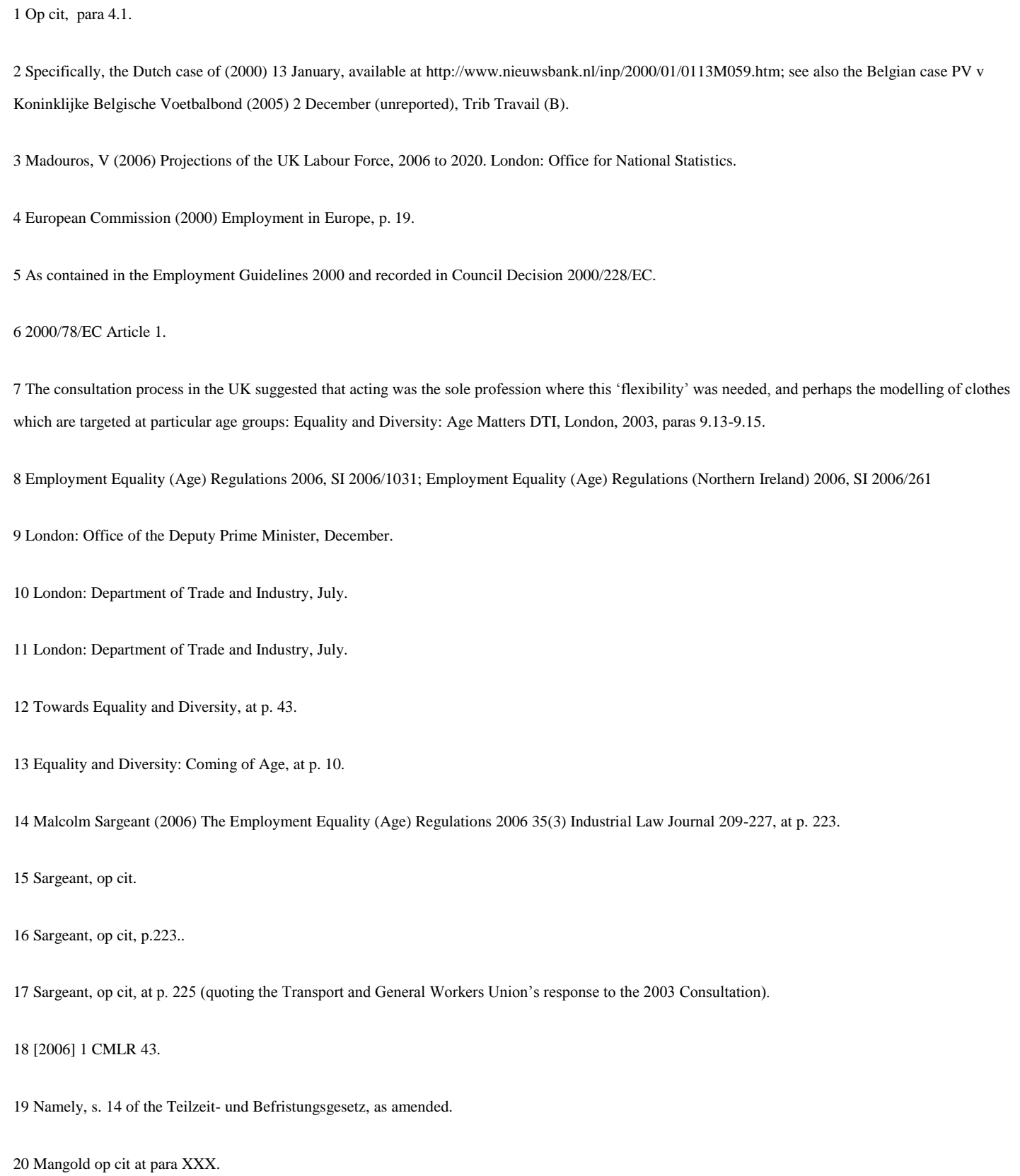


21 [1986] ECR 723.

22 Sebastian Krebber (2005/06) The Social rights Approach of the ECJ to Enforce European Employment Law 27 Comparative Labour Law and Policy Journal $377-403$, at p. 381

23 Dagmar Schiek (2004) The ECJ Decision in Mangold 33(4) Industrial Law Journal 329, at p. 344.

24 Mangold, op cit, at para 74

25 Krebber, op cit, especially at pp. 389-392.

26 Mangold op cit at para XXX.

27 Malcolm Sargeant (2006) The Employment Equality (Age) Regulations 2006 35(3) Industrial Law Journal 209-227, at p. 222.

28 Mangold op cit at para XXX.

29 Mangold, op cit at para 78.

30 Anthony Arnulll (2006) Out With the Old... 31(1) European Law Review 1-2; Elise Muir (2006) Enhancing the Effects of Community Law on National Employment Policies 31(6) European Law Review 879-891; Krebber, op cit.

31 Case C-411/05

32 Palacious, op cit, at para 52

33 Op cit, para 64

34 Op cit, para 67

35 Op cit, para 72

36 Op cit, at para 72

37 Op cit, para 76

38 Op cit, para 89

39 Op cit, para 96

40 [2007] IRLR 989 at para/page?

41 Michael Connolly (2007) The ECJ Signals a Light Touch Towards Age Discrimination and Compulsory Retirement 8(Nov) Employment Law Bulletin 1, at p. 3 .

42 [1999] 2 AC 554 s. 69: Connolly, op cit at p.3.

43 [2008] 1 CMLR 17, otherwise known as the Heyday case.

442007 WL 4190633.

452007 WL 4190633, at para 18

46 Claire Kilpatrick (2007) Age, Retirement and the Employment Contract 36(1) Industrial Law Journal 119-135, at p. 133.

47 Kilpatrick, op cit at p. 132. 
48 Sargeant, op cit, at p. 226

49 Jonathan Swift (2006) Justifying Age Discrimination 35(3) Industrial Law Journal 228-244 at p. 241,

50 Banksbo et al op cit.

51 In the course of a football match, elite referees will spend $25 \%$ of their time in the high-intensity activity zone - i.e., they will be engaged in running at high speed or sprinting. In February 2008, UEFA's new elite referees attended fitness training in Cyprus, where the test included completing six 40m sprints each in under 6.2 seconds; and interval tests of twenty 150m runs each in under thirty seconds. Thirty-two of the 34 participants passed: Hart, S (2008) New Referees Fit for Task available at www.uefa.com/uefa/keytopics/kind=524288/newsid=653566.html last accessed 8th February 2008. J. Casajus and G Castagna (2007) Aerobic Fitness and Field Test Performance in Elite Spanish Soccer Referees of Different Ages 10(6) Journal of Science and Medicine in Sport 382-389; J.

Martin, K. Tolfrey, K. Smith, K. George and A. Jones (2003) The Development and Validation of a Field-based Fitness Test for Rugby Union Referees 21 (40 Journal of Sports Sciences 282

52 P. Krustup and J. Bangsbo (2001) Physiological demands of top-Class Soccer Refereeing in Relation to Physical Capacity: Effect of Intense Intermittent Exercise Training 19 Journal of Sports Sciences 881-981.

53 J Bangsbo and P Krustup (2001) Physical Activity and Match Performance of Top-class Referees in Relation to Physical Capacity 19(11) Journal of Sports Sciences 524

54 Regulations For the Registration and Control of Referees: "Rules of the game" available at http://www.thefa.com/default.htm, p. 91 last accessed 3rd March 2008.

55 http://news.bbc.co.uk/sport1/hi/football/europe/4312089.stm last accessed 3rd March 2008

56 FIBA Europe (2007) Regulations available at www.fibaeurope.com last accessed 8th February 2008.

57 FIBA (2006) International Regulations available at www.fiba.com last accessed 8th February 2008

58 Personal conversation with representative of FIBA Europe 19th February 2008.

59 International Ice Hockey Federation (2003) Official's (sic) Development Program available at www.iihf.com, p. 53 last accessed 8th February 2008.

60 IIHF Bylaws article 1101: personal communication from Konstantin Komissarov, IIHL Sport Development manager 8th February 2008.

61 Swift, op cit, at p. 235 .

62 Roberto Branco Martins (2003) Promoting the Social Dialogue in European Professional Football International Sports Law Journal 39-41.

63 Lloyd Freeman (2007) The UCI ProTour: An Enduring Reform or a 'Train Wreck' Waiting to Happen? 2(1) Australian and New Zealand Sports Law Journal $15-58$.

64 UEFA Organizational Regulations 2007Article 20

65 Paul Marginson (year) Industrial Relations at European Sector Level: The Weak Link? 26(4) Economic and Industrial Democracy 511 - ?? at p. 516.

66 http://ec/europa.eu/governance/impact/docs/key_docs/laeken_concl.en.pdf, last accessed March 3rd 2008.

67 Rob de Boer, Hester Benedictus, Marc van der Meer (year) Broadening without Intensification: The added Value of the European Social and Sectoral Dialogue 11(1) European Journal of Industrial Relations 50-??

\section{${ }^{68}$ Nicholas Eberstadt and Hans Groth (2007) Healthy Old Europe 86 Foreign Affairs 55}

69 As to which see for example J. Casajus and G. Castagna (2007) Aerobic Fitness and Field Test Performance in Elite Spanish Soccer Referees of Different Ages 10(6) Journal of Science and Medicine in Sport 382-389; J. Martin, K. Tolfrey, K. Smith, K. George and A. Jones (2003) The Development and Validation of a Field-based Fitness Test for Rugby Union Referees 21(4) Journal of Sports Sciences 282. 
